\author{
Dariusz NIEDŹWIEDZKI \\ Uniwersytet Jagielloński \\ dariusz.niedzwiedzki@uj.edu.pl
}

\title{
DYLEMATY I KONTROWERSJE WOKÓŁ INTEGRACJI EUROPEJSKIEJ - WPROWADZENIE
}

$\mathrm{P}$ roces integracji europejskiej w sposób bezpośredni lub pośredni dotyka życia codziennego mieszkańców Europy praktycznie we wszystkich jego aspektach. Związane z nim zjawiska modyfikują poglądy i zachowania w sferze ekonomicznej i politycznej, wpływają na zmiany o charakterze kulturowym i społecznym, odciskają piętno w sferze działań publicznych i prywatnych obywateli Europy. W konsekwencji wywołują u nich szereg dylematów dotyczących oceny integracji i wzbudzają liczne kontrowersje związane z przebiegiem, skutkami i przyszłością tego procesu.

Artykuły umieszczone w tym numerze czasopisma stanowią efekt warsztatów naukowych i dwudniowej konferencji zorganizowanej w Instytucie Europeistyki UJ ${ }^{1}$. Te przedsięwzięcia zgromadziły kilkudziesięciu badaczy z Polski i zagranicy, którzy skupili się na dwóch zagadnieniach ilustrujących dylematy i kontrowersje związane z procesem integracji europejskiej. Pierwszym z nich jest problem eurosceptycyzmu w swojej teoretycznej i empirycznej postaci. Drugim - postawy Polaków, w szczególności mieszkańców obszarów małomiasteczkowych i wiejskich, wobec procesu integracji i akcesji Polski do Unii Europejskiej.

Analizowane zjawiska eurosceptycyzmu i stosunku zwykłych obywateli do UE odnoszone są do opinii, postaw i zachowań dotyczących szeroko rozumianego

1 Dwudniowa konferencja i poprzedzające ją warsztaty zostały zorganizowane w dniach 29-31 V $2015 \mathrm{r}$. w ramach realizacji projektu badawczego „Polska lokalna wobec integracji europejskiej - dekada doświadczeń", sfinansowanego ze środków Narodowego Centrum Nauki przyznanych na podstawie decyzji numer DEC- 2011/03/B/HS6/01163. Warsztaty poświęcone problematyce eurosceptycyzmu w Polsce i Europie zostały dodatkowo dofinansowane przez stowarzyszenie UACES, a pierwszy dzień konferencji, także poświęcony problematyce eurosceptycyzmu, odbył się w ramach międzyuczelnianej inicjatywy „10 seminariów na 10-lecie członkostwa Polski w UE” (zob.: http://www.10seminariow-ie. uw.edu.pl/). 
pojęcia integracji europejskiej, wykraczającego poza najczęściej stosowany formalno-instytucjonalny efekt działania Unii Europejskiej. W naszym rozumieniu obejmuje ono:

1) transfer wartości lub standardów z poziomu europejskiego na poziom narodowy, ich zastosowanie i efekt wywołany implementacją,

2) wpływ integracji europejskiej na państwo narodowe, zarówno w fazie przedakcesyjnej, jak i poakcesyjnej, w tym także przenoszenie standardów europejskich poza granice Europy,

3) budowanie europejskiej unii politycznej, w tym rozwój europejskich instytucji $\mathrm{i}$ ich kompetencji,

4) skuteczność poszczególnych polityk unijnych mierzona udaną ich implementacją do narodowych systemów politycznych,

5) nadawanie wspólnych sensów w rzeczywistości, budowanie wspólnych elementów kulturowych przez Europejczyków.

Oba analizowane zjawiska odnoszą się także do problematyki przyszłości procesu integracji oraz miejsca w nim Polski i innych krajów członkowskich. „Europa ojczyzn”, „Europa regionów”, „Europa - superpaństwo”, „Europa deliberatywna” to modele dobrze opisane w literaturze. Naszym zdaniem wybór spośród nich jest ważnym przejawem posiadanej tożsamości europejskiej i stosunku do integracji.

Artykuły zamieszczone w tym numerze pisma stanowiące efekt realizacji projektu badawczego „Polska lokalna wobec integracji europejskiej - dekada doświadczeń” wymagają dodatkowych uwag o charakterze metodologicznym. Są one bowiem oparte na przeprowadzonych badaniach empirycznych z wykorzystaniem antropologicznej metody intensywnych badań terenowych. Badania terenowe zostały zrealizowane w okresie od jesieni 2012 do wiosny 2014 r. w miejscowościach sześciu gmin położonych w trzech różnych regionach Polski. Ich wybór był zdeterminowany przez fakt, że projektowane badania nawiązują do zrealizowanego przez nasz zespół w latach 1999-2001 projektu „Postawy społeczeństwa polskiego wobec integracji europejskiej”. Naszym celem było bowiem przeanalizowanie zmian w opiniach, postawach i zachowaniach mieszkańców tych samych sześciu gmin: Zwierzyniec, Szczebrzeszyn, gmina wiejska Nowa Ruda, Szczytna, gmina wiejska Leżajsk, Nowa Sarzyna.

Realizując projekt, staraliśmy się znaleźć odpowiedzi na pytanie o zmiany, jakie zaszły w sferze deklaracji oraz postawach i zachowaniach mieszkańców tych gmin wobec procesu integracji europejskiej i akcesji Polski do UE. Intersujące nas zmiany badaliśmy w trzech analitycznie wyróżnionych sferach integracji europejskiej: organizacyjno-instytucjonalnej, ideowo-normatywnej i społeczno-psychologicznej. Nie mamy bowiem wątpliwości, że opinie, postawy i zachowania wyrażające stosunek do procesu integracji europejskiej uwarunkowane są licznymi i różnorodnymi czynnikami. Naszym zdaniem w badanych społecznościach lokalnych do najważniejszych należą: kompetencje do bycia Europejczykiem, interesy oraz możliwość ich realizacji/blokowania w procesie integracji, doświadczenia związane z działaniem w integrującej się Europie,

Zob.: Polska lokalna wobec integracji europejskiej, red. Z. Mach, D. Niedźwiedzki, Kraków 2002. 
źródła wiedzy o integracji europejskiej i UE, sukces/porażka indywidualna i grupowa w procesie zmian zachodzących w Polsce.

Metodyka badań, zastosowane w niej metody, techniki i narzędzia badawcze były ściśle związane z zakresem i specyfiką sformułowanych w projekcie problemów badawczych. Podstawę uzyskania danych stanowił pogłębiony wywiad problemowy oraz technika obserwacji. Zostały one uzupełnione analizą dokumentów życia społecznego, czyli występujących w dowolnej postaci dowodów istnienia określonych faktów i wydarzeń społecznych.

Tego typu metodyka badawcza jest naszym zdaniem najlepiej dostosowana do analizowania elementów świadomościowych ludzi, ich uczuć, poglądów i postaw dotyczących kontaktów z innymi/obcymi, a instytucje europejskie, ich pracownicy i inni Europejczycy tak właśnie są pozycjonowani. Pozwala także być otwartym na różnego rodzaju niespodzianki, elementy zaskoczenia w sytuacji empirycznej, wymagające elastyczności w stosowaniu narzędzia badawczego i jego modyfikacji czy uzupełnienia w trakcie badań.

Istota zastosowanych przez nas badań terenowych polega na obserwowaniu i rozmawianiu z ludźmi w ich naturalnym otoczeniu, interakcjach, które przebiegają w ich warunkach kulturowych, w ich własnym języku. Wynikające $z$ tego specyficzne relacje pomiędzy badaczem i badanym, wyznaczane przez bezpośredni kontakt oraz odwoływanie się do kompetencji i aktywności badanych podmiotów, wymaga szczególnej dbałości o trafność i rzetelność uzyskanych danych. Warto przy tym zauważyć, że trafność badania jakościowego wchodzi w konflikt z jego rzetelnością. Rzetelność wymaga bowiem standaryzacji, a trafność przeciwnie, odchodzenia od standaryzacji. Jeśli badacz troszczy się o autentyczność tekstu, to słucha badanego z pewną dozą krytycyzmu, gotów zawsze upewnić się co do znaczenia określonych treści. To jednak oznacza, że nie trzyma się ustalonej procedury, odchodzi od standaryzacji i otwiera możliwość pojawienia się przypadkowych danych.

W efekcie w naszym podejściu ważniejsze niż trafność wydaje się ugruntowanie uzyskiwanej w badaniach wiedzy, czyli zachowywanie w trakcie jej zdobywania otwartości i braku stronniczości. Ugruntowanie oznacza zbieranie faktów i trzymanie się ich, przy zachowaniu świadomości popełniania błędów, zdobywania danych artefaktycznych, pomijania czy przeoczania ważnych danych. Kontroli tego ugruntowania zdobywanej wiedzy służy triangulacja, umożliwiająca konfrontowanie różnych wersji uzyskanych danych uzależnionych od źródła, metody, badacza i teorii. W przypadku tej pierwszej porównuje się dane pochodzące od różnych osób, z różnych miejsc terenu i z różnego czasu. Dlatego ogromną wagę przywiązujemy do analizy danych uzyskanych przez innych badaczy. Triangulacja metod oznacza porównanie danych zebranych różnymi metodami, np. jak w przypadku naszych zamierzeń badawczych za pomocą obserwacji i wywiadu. Ponadto konfrontowaliśmy je z danymi zastanymi pochodzącymi z szeroko rozumianych dokumentów życia społecznego. Triangulacja badaczy oznacza porównanie wniosków, do których dochodzi kilku badaczy pracujących w tym samym terenie nad tym samym problemem. Osiągnęliśmy taki stan dzięki częściowo niezależnemu postępowaniu badawczemu kilku członków zespołu. 
Wreszcie triangulacja teorii to konfrontacja interpretacji danych w różnych perspektywach teoretycznych.

Zastosowany przez nas pogłębiony wywiad problemowy jest połączeniem wywiadu biograficznego czy narracyjnego z jednej i kwestionariuszowego z drugiej strony - w literaturze nosi on także nazwę ustrukturyzowanego wywiadu problemowego. $Z$ tym pierwszym wiąże go umożliwienie respondentowi podjęcia swobodnej opowieści o swoim życiu, doświadczeniach, opiniach, postawach i podejmowanych działaniach. $\mathrm{Z}$ tym drugim - ukierunkowywanie narracji na problemy interesujące badacza poprzez podchwytywanie w opowieści określonych wątków i zadawanie dodatkowych pytań. Dwie kwestie wydają się istotne dla powodzenia zastosowania tej techniki i uzyskania wartościowych danych empirycznych. Po pierwsze, stworzenie warunków przeprowadzenia badań, które pozwolą respondentowi zachować poczucie bezpieczeństwa. Jest to szczególnie istotne w sytuacji, gdy respondentami są osoby, którym ze względu na nieustabilizowaną pozycję materialną i status społeczny towarzyszy poczucie niepewności i zagrożenia. Po drugie, zachowanie „miękkiej” reprezentatywności w badaniach, czyli uzyskanie wywiadów od przedstawicieli poszczególnych kategorii mieszkańców badanych gmin, wyróżnionych ze względu na jakieś cechy społeczne.

Problematyka kwestionariusza wywiadu odnosiła się do kilku poziomów analizy, z których dwa wydają się kluczowe. Pierwszy dotyczy stanu wiedzy, źródeł informacji i działań badanych związanych z szeroko rozumianym procesem integracji europejskiej. Drugi miał przybliżyć nas do zrozumienia i wyjaśnienia wpływów tych zmiennych na poczucie tożsamości, w szczególności europejskiej, oraz kształtowania się na tej podstawie poglądów, opinii i postaw wobec integracji europejskiej. Oczywiście wymaga to dotarcia poprzez wskaźniki do ewentualnych zmian w systemach wartości, poglądach i postawach, które często mają charakter nieuświadomiony. Merytorycznie kwestionariusz wywiadu problemowego obejmował trzy sfery problemowe procesu integracji europejskiej: organizacyjno-instytucjonalną (wiedza o instytucjach zaangażowanych w proces integracji i jej źródła, bilans zysków i strat wejścia Polski do UE, ocena efektywności władzy w działaniach związanych z procesem integracji), ideowo-normatywną (granice Europy i europejskości, znaczenie i przyszłość integracji europejskiej, ukierunkowanie ideowe i interakcyjne różnych płaszczyzn tożsamości), społeczno-psychologiczną (udział w działaniach podmiotów polityki instytucjonalnej i nieinstytucjonalnej związanych z procesem integracji, doświadczenia interakcyjne i więzi społeczne z Europejczykami, Europa i Europejczycy w ramach dychotomicznego podziału „swój” - „obcy”).

Jak już wspominałem, badaniami zostały objęte te same społeczności lokalne, w których przeprowadziliśmy badania terenowe w latach 1999-2000, co pozwala na wprowadzenie do analizy perspektywy diachronicznej. Ponadto przeprowadzone przez nas badania miały charakter jakościowy. W efekcie o zakresie generalizacji danych możemy mówić tylko w kategoriach tzw. miękkiej reprezentatywności. Staraliśmy się bowiem objąć w badaniach reprezentantów społeczności lokalnych posiadających obecne w nich zróżnicowane cechy socjologiczne, takie jak: wiek, płeć, wykształcenie, zawód wykonywany i miejsce zamieszkania. Wśród badanych osób liczną grupę stanowili 
formalni i nieformalni liderzy społeczni. Dotarcie do nich uznaliśmy za niezwykle ważne ze względu na duże znaczenie liderów w kształtowania opinii, postaw i zachowań mieszkańców społeczności. Łącznie przeprowadziliśmy w badanych gminach 202 wywiady pogłębione, z czego mniej więcej $25 \%$ to wywiady z liderami społeczności lokalnych. Przyjęte założenia metodologiczne i metodyka badań sprawiają, że wszelkie wnioski mogą być odnoszone do badanych społeczności, a uogólniane w szerszym zakresie tylko o tyle, o ile przyjmiemy, że poprzez posiadane cechy reprezentują pewne typy społeczności w Polsce

Analiza danych zarówno zastanych, jak i wywołanych miała przede wszystkim charakter jakościowy i została oparta na metodzie kodowania (wstępnego i analitycznego) danych empirycznych oraz tzw. metodzie ośmiu pytań badawczych. Ta druga obejmuje szukanie poprzez analizowanie danych odpowiedzi na kluczowe pytania w naukach społecznych. Jeżeli badanym przez nas zjawiskiem są opinie, postawy i zachowania wobec integracji europejskiej, to chcielibyśmy odpowiedzieć na następujące pytania: Jakie są typy badanego zjawiska? Jak często występuje badane zjawisko? Jak wielkie jest badane zjawisko? Jaką strukturę ma badane zjawisko? Jakie procesy występują w badanym zjawisku? Jakie są przyczyny badanego zjawiska? Jakie są konsekwencje badanych zjawisk? Gdzie występuje i czym jest podmiotowa sprawczość aktorów uwikłanych w badane zjawisko?

\section{Oznaczenia kodowe gmin i miejscowości, w których przeprowadzono wywiady}

L/CH - gmina wiejska Leżajsk, miejscowość Chałupki Dębniańskie

L/D - gmina wiejska Leżajsk, miejscowość Dębno

L/G - gmina wiejska Leżajsk, miejscowość Giedlarowa

L/BK - gmina wiejska Leżajsk, miejscowość Brzóza Królewska

L/L - gmina wiejska Leżajsk, miejscowość Leżajsk

L/P - gmina wiejska Leżajsk, miejscowość Piskorowice

L/RZ - gmina wiejska Leżajsk, miejscowość Rzuchów

L/W - gmina wiejska Leżajsk, miejscowość Wierzawice

NR/B - gmina Nowa Ruda, miejscowość Bożków

NR/D - gmina Nowa Ruda, miejscowość Dzikowiec

NR/J - gmina Nowa Ruda, miejscowość Jugów

NR/L - gmina Nowa Ruda, miejscowość Ludwikowice Kłodzkie

NR/NR - gmina Nowa Ruda, miejscowość Nowa Ruda

NR/P - gmina Nowa Ruda, miejscowość Przygórze

NR/S - gmina Nowa Ruda, miejscowość Nowa Ruda-Słupiec

NR/SO - gmina Nowa Ruda, miejscowość Sokolec

NR/W - gmina Nowa Ruda, miejscowość Wolibórz

NS/Ł - gmina Nowa Sarzyna, miejscowość Łętownia

3 Więcej w sprawie charakterystyki badanych gmin zob.: Z. Mach, D. Niedźwiedzki, Wstęp, [w:] Polska lokalna..., s. 12-14. 
NS/MŁ - gmina Nowa Sarzyna, miejscowość Majdan Łętowski

NS/NS - gmina Nowa Sarzyna, miejscowość Nowa Sarzyna

NS/S - gmina Nowa Sarzyna, miejscowość Sarzyna

NS/WŁ - gmina Nowa Sarzyna, miejscowość Wólka Łętowska

NS/WŻ - gmina Nowa Sarzyna, miejscowość Wola Żarczycka

S/B - gmina Szczebrzeszyn, miejscowość Bodaczów

S/BD - gmina Szczebrzeszyn, miejscowość Brody Duże

S/BM - gmina Szczebrzeszyn, miejscowość Brody Małe

S/K - gmina Szczebrzeszyn, miejscowość Kawęczyn

S/SZ - gmina Szczebrzeszyn, miejscowość Szczebrzeszyn

SZ/Ł - gmina Szczytna, miejscowość Łężyce

SZ/SZ - gmina Szczytna, miejscowość Szczytna

SZ/W - gmina Szczytna, miejscowość Wolany

SZ/N - gmina Szczytna, miejscowość Niwa

Z/B - gmina Zwierzyniec, miejscowość

Z/G - gmina Zwierzyniec, miejscowość Guciów

$\mathrm{Z} / \mathrm{K}$ - gmina Zwierzyniec, miejscowość Kosobudy

$\mathrm{Z} / \mathrm{O}$ - gmina Zwierzyniec, miejscowość Obrocz

$\mathrm{Z} / \mathrm{S}$ - gmina Zwierzyniec, miejscowość Sochy

Z/W - gmina Zwierzyniec, miejscowość Wywłoczka

$\mathrm{Z} / \mathrm{Z}$ - gmina Zwierzyniec, miejscowość Zwierzyniec

Po kodzie literowym znajduje się kod dwucyfrowy oznaczający numer wywiadu w danej miejscowości.

Dr hab. Dariusz NIEDŹWIEDZKI - ukończył studia ekonomiczne (1986) i socjologiczne (1988), doktoryzował się w zakresie socjologii (1996) i w tej dziedzinie uzyskał habilitację (2011). Adiunkt w Instytucie Europeistyki Uniwersytetu Jagiellońskiego. Jego zainteresowania badawcze dotyczą problematyki tożsamości społecznej, zmian społecznych i kulturowych zachodzących w integrującej się Europie, związków między sferą kultury i polityki, kulturowych i społecznych konsekwencji procesów migracyjnych oraz konfliktów etnicznych i regionalnych. Autor, współautor i redaktor kilku książek, ostatnio wydał: Migration and Europeanization (2009), Migracje i tożsamość. Od teorii do analizy przypadku (2010), Kultura, tożsamość i integracja europejska (2014). 